\title{
DDR2 Gene
}

National Cancer Institute

\section{Source}

National Cancer Institute. DDR2 Gene. NCI Thesaurus. Code C24333.

This gene plays a role in extracellular matrix communication processes and receptor-

mediated signal transduction. 